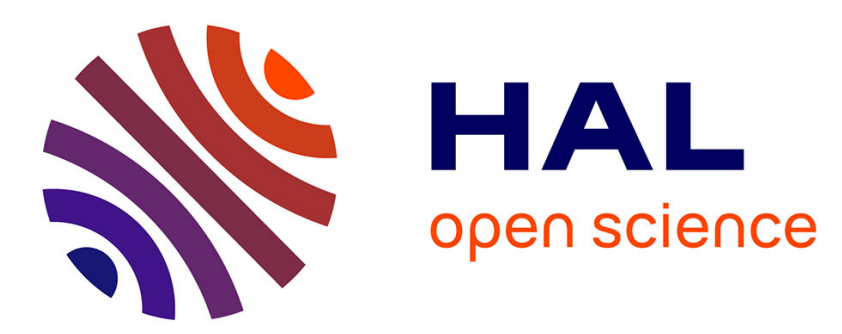

\title{
Monthly means of daily solar irradiation over Egypt estimated from satellite database and various empirical formulae
}

Mossad El-Metwally, Lucien Wald

\section{- To cite this version:}

Mossad El-Metwally, Lucien Wald. Monthly means of daily solar irradiation over Egypt estimated from satellite database and various empirical formulae. International Journal of Remote Sensing, 2013, 34, pp.8182-8198. 10.1080/01431161.2013.834393 . hal-00865173

HAL Id: hal-00865173

https://hal-mines-paristech.archives-ouvertes.fr/hal-00865173

Submitted on 24 Sep 2014

HAL is a multi-disciplinary open access archive for the deposit and dissemination of scientific research documents, whether they are published or not. The documents may come from teaching and research institutions in France or abroad, or from public or private research centers.
L'archive ouverte pluridisciplinaire $\mathbf{H A L}$, est destinée au dépôt et à la diffusion de documents scientifiques de niveau recherche, publiés ou non, émanant des établissements d'enseignement et de recherche français ou étrangers, des laboratoires publics ou privés. 


\title{
Monthly means of daily solar irradiation over Egypt estimated from satellite database and various empirical formulae
}

\author{
Mossad EL-METWALLY ${ }^{1}$ and Lucien WALD ${ }^{2}$ \\ ${ }^{1}$ Department of Physics, Faculty of Science, Port Said University, Port Said, Egypt. \\ Corresponding author: melmetwally@yahoo.com \\ ${ }^{2}$ MINES ParisTech, Centre Observations, Impacts, Energie, BP 207, 06904 Sophia \\ Antipolis, France
}

Short title: Comparing solar radiation from satellite database and empirical models over Egypt

\begin{abstract}
Monthly means of daily solar irradiation retrieved from the HelioClim-3 version 3 database $(\mathrm{HC} 3 \mathrm{v} 3)$, elaborated from Meteosat satellite images, were tested at 14 Egyptian stations along with the model of Yang, Koike and Ye (YKY) and 10 empirical models (EMs) for the period 2004 to 2009. YKY and EMs were fitted to measurements from the period 1980 to 1989. Overall, HC3v3 exhibits a bias of $0.4 \mathrm{MJ} \mathrm{m}^{-2}$ (i.e. $2 \%$ of the mean of the observations -similar to the best EMs). The root mean square error (RMSE) was $1.8 \mathrm{MJ} \mathrm{m}^{-2}(9 \%)$ for $\mathrm{HC} 3 \mathrm{v} 3$ which is lower than for most EMs. Coefficients of determination $\left(\mathrm{R}^{2}\right)$ were greater than 0.9 for most models. The regression line between estimates and observations exhibits a slope of 1.01 and an intercept of $0.09 \mathrm{MJ} \mathrm{m}^{-2}$ for $\mathrm{HC} 3 \mathrm{v} 3$, reflecting a better performance than other models. HC3v3 shows remarkable constant performance as a function of irradiation or cloudiness compared with EMs and YKY. In general, HC3v3 is preferred to EMs when estimating monthly means of daily solar irradiation in Egypt. It is suggested that more effort is needed towards the validation and promotion of $\mathrm{HC} 3 \mathrm{v} 3$ before researchers and practitioners use it rather than EMs.
\end{abstract}

Keywords: agro-meteorology; remote sensing; Meteosat; HelioClim; Heliosat-2; Africa; solar radiation; solar energy; validation 


\section{Introduction}

Solar radiation reaching the ground is the most fundamental renewable energy source in nature. Its knowledge and its geographical distribution are of prime importance for numerous solar applications. Climate science requires reliable and sufficiently detailed data to understand the radiative forcing of climate change. Similar data are needed for mid- and long-term energy planning to exploit solar radiation for use in urban buildings and energy systems for heating and electrical power generation, or in agro-meteorology. Of particular interest to these applications are monthly means of daily irradiation, noted $G$ hereafter. The daily irradiation is the amount of energy that reaches a horizontal surface of $1 \mathrm{~m}^{2}$ at ground level during a day.

The measurement of solar radiation requires costly equipment such as pyranometers. Unfortunately, for many developing countries, this type of instrument is not easily available due to the cost, the required maintenance, and the calibration requirements of the measuring equipment. In such situations where devices measuring solar radiation are scarce, the use of empirical models (EMs) to estimate solar radiation from available meteorological parameters is a common practice. In addition, though several African countries have measuring stations, only a few data sets are stored in the World Radiation Data Centre (WRDC), the official repository of the World Meteorological Organisation for solar radiation data. At the time of writing, daily irradiation at surface are available to anyone from WRDC only at two stations in Africa, except Egypt which has 14 measuring stations. This is another reason to use EMs.

Several EMs have been published which estimate $G$ from the relative sunshine duration $S$, i.e., the ratio of the recorded sunshine duration to the theoretical or astronomical duration (Ångström 1924; El-Metwally 2005; Martínez-Lozano et al.,1984; Prescott 1940; Suehrcke 2000). Others use the surface air temperature as input (Bristow and Campbell 1984) or the cloudiness measured in oktas or tenths (ElMetwally 2004; Supit and Kappel 1998). These models may use several inputs among these three already cited plus others such as relative humidity or content of the 
atmospheric column in water vapour (Abdalla 1994; Garg and Garg 1982; Gul et al., 1998; Maghrabi 2009).

Satellite sensors provide another alternative to the sparse coverage of radiometric networks, since they can produce irradiation data over large regions on a high spatial resolution grid with an appropriate processing (Aksoy 2011; Pinker and Laszlo 1992; Wang et al. 2000; Wloczyk and Richter 2006). Meteorological geostationary satellites such as the Meteosat series are widely used: they offer synoptic and accurate views of the cloud fields, which are the major causes of changes in solar radiation available at the surface of the earth. Various algorithms and methods have been developed for estimating surface solar radiation from images of the Meteosat satellites (Cano et al. 1986; Diabaté et al. 1988; Ineichen et al. 2009; Kandirmaz et al. 2004; Möser and Raschke 1984; Moussu et al. 1989). The Heliosat-2 method (Rigollier et al. 2004) is one of them and has been used by several authors with good performances (Abdel Wahab et al. 2010; Aculinin 2008; Al-Jumaily et al. 2010; Blanc et al. 2011; Dürr and Zelenka 2009; Lefèvre et al. 2007; Marie-Joseph et al. 2013; Moradi et al. 2009; Vazquez et al. 2009; Wald et al. 2011).

The goal of the present study is to compare $G$ estimated from Meteosat images to ground measurements and to EMs. The underlying question is how beneficial are Meteosat images for the estimation of ground solar radiation as compared to EMs which are easier to implement. The study applies to Egypt which has 14 measuring stations, a sufficiently large number to draw solid conclusions for a northern Africa desert climate.

\section{Materials and methods}

\subsection{The climate of Egypt}

The general climate of Egypt is subtropical. Spring and autumn can be considered as transitional seasons. They are characterized by small-scale depressions moving across the Great Sahara. The weather associated with these depressions is generally hot, dry and dusty. In particular, spring is dominated by frequent chained depressions, called the Khamsin phenomenon (El-Wakil et al. 2001). The Nile River and its adjacent narrow cultivated belts have only a limited and local influence on the Egyptian 
climate (El-Wakil, et al., 2001). Diabaté et al. (2004) have proposed a division of Egypt in approximately four climatic areas with respect to the optical clearness of the sky (table 1):

- the lower Egypt along the north coast (north of $30^{\circ} \mathrm{N}$ latitude) has a rather Mediterranean climate with a mild rainy winter and a dry, warm and rainless summer. The soil is generally sandy. Representative meteorological stations are Barrani and Matruh (Table 1);

- the arid Sinai peninsula. The sky is very clear in summer: more than $65 \%$ of the solar radiation at the top of the atmosphere reaches the surface as an average. This fraction decreases down to $55 \%$ in November and December. Rafah and Arish stations are located in this peninsula;

- the area close to Cairo experiences a semi-arid warmer dry climate. Cairo is an industrialized area with more than 16 million inhabitants and is one of the most important megacities in the world. Stations are Cairo, Bahtiem and Wadi El-Natron;

- the upper Egypt is the southern part of Egypt and has a dry desert climate. The soil is usually sandy but granite rocks may be present. Variations in cloudiness are more marked in the northern part than in the southern one. Stations Nekhel, Malwi, Hurgada, Asyut, South Valley, Kharga and Aswan are located in this area.

Table 1 lists the fourteen stations that are used in this study. They are deployed from North to South. The length of the available data set differs from one station to the other in the period from 2004 to 2009. Asyut and Kharga exhibit long data sets covering more than 60 months. On the contrary, Bahtiem and Malwi offer only 23 and 24 months, respectively. Nekhel, Rafah, and Hurgada offer even less data: 10, 14 and 14 months, respectively.

Besides the geographical coordinates, Table 1 reports average values for air temperature $\left(T_{a}\right)$, relative humidity $(R H)$, relative sunshine duration $(S)$, clearness index and $G$, for the period 2004 to 2009 . The main features of the climate of Egypt have a marked latitudinal trend. $T_{a}$ increases from North to South, whereas the cloud amount, $R H, S$ and $G$ decrease. Low $S$ and $G$ values at semi-arid warmer climate 
stations may be due to the air pollution caused by traffic and industrial activities in Cairo area and extension of its influence to the neighbouring stations Bahtiem and Wadi El-Natron (El-Wakil et al. 2001; El-Metwally et al. 2008; El-Metwally, 2013).

\subsection{Meteorological measurements}

Meteorological data, namely air temperature (average: $T_{a}$; maximum: $T_{\max }$ and minimum: $\left.T_{m i n}\right)$, surface pressure $(P)$, cloud cover amount $\left(C_{m}\right), R H, S$ and $G$ have been obtained from the Egyptian Meteorological Authority (EMA) for the period 2004 to 2009. Missing data in $S$ and $G$ were replaced by those available at the World Radiation Data Centre (WRDC). Data are averaged on a monthly basis. From hereafter, the variables $S, T_{a}, T_{\max }, T_{\min }, \mathrm{P}, C_{m}, R H, S$, and $G$ are monthly means.

Solar radiation is measured at EMA stations by an Eppley Precision Spectral Pyranometers (PSPs). The accuracy of these pyranometers corresponds to Class 1 according to the World Meteorological Organization classification (WMO, 1981). A spare instrument is calibrated every 5 years in Davos, Switzerland, and is traceable to the World Radiometric Reference (WRR) (WRC, 1985 and 1995).The other instruments are calibrated each year against this reference instrument. According to the calibration certificate of the manufacturers, their sensitivity (or responsivity) is approximately $9 \mu \mathrm{V} \mathrm{W}^{-1} \mathrm{~m}^{-2}$. Their temperature dependence is $\pm 1 \%$ for an ambient temperature range of $-20{ }^{\circ} \mathrm{C}$ to $+49{ }^{\circ} \mathrm{C}$. The linearity is $\pm 0.5 \%$ from 0 to $2800 \mathrm{~W} \mathrm{~m}^{-2}$, and the cosine error is $\pm 1 \%$ from normalization $0^{\circ}$ to $70^{\circ}$ and $\pm 3 \%$ for $70^{\circ}$ to $80^{\circ}$ (ElMetwally, 2013). The accuracy of calibration is approximately $\pm 3-4 \%$ (El-Metwally, 2004; Omran, 2000).

\subsection{Use of Meteosat images}

At MINES ParisTech, Meteosat satellite images are routinely processed by means of the Heliosat-2 method (Rigollier et al. 2004) and the estimated irradiation values are stored in the HelioClim databases covering Europe, Africa and the Atlantic Ocean (Blanc et al. 2011). The Heliosat-2 method is detailed elsewhere and only a brief outline is given here.

The Heliosat-2 method is based on the principle that a difference in the signal received by the sensor is due to a change in the apparent albedo, which is itself caused 
by a change in the atmospheric transmittance or ground albedo. The atmospheric transmittance is also called clearness index and is defined as the ratio of the irradiation at surface divided by the irradiation at the top of the atmosphere. A cloud index, $n$, is then formulated, which is correlated to the solar radiation. For time $t$ and pixel $(i, j)$ the cloud index $n^{t}(i, j)$ is defined as:

$$
n^{t}(i, j)=\left[\rho^{t}(i, j)-\rho_{g}^{t}(i, j)\right] /\left[\rho_{\text {cloud }}^{t}(i, j)-\rho_{g}^{t}(i, j)\right]
$$

where $\rho^{t}(i, j)$ is the apparent albedo observed by the satellite. $\rho_{g}^{t}(i, j)$ is the apparent albedo over the ground under clear sky and is obtained by taking the minimum of a time series of apparent albedoes. $\rho_{\text {cloud }}^{t}(i, j)$ is the albedo of the brightest clouds. The apparent albedo $\rho^{t}(i, j)$ is close to the apparent albedo over the ground if the sky is clear and $n$ is close to $0 . n$ is close to 1 on overcast days.

Roughly speaking, the irradiation $G^{t}(i, j)$ is computed as:

$$
G^{t}(i, j)=\left(1-n^{t}(i, j)\right) G c^{t}(i, j)
$$

where $G c^{t}(i, j)$ is the irradiation that would be observed if the sky were clear. $G c^{t}(i, j)$ is estimated by the ESRA clear-sky model (Rigollier et al. 2000) corrected by Geiger et al. (2002). Inputs to this model are the solar zenith angle, the elevation of the site and the Linke turbidity factor (Linke, 1922) for a relative air mass of $2, T_{L}$. Remund et al. (2003) constructed a series of 12 maps, one per month, covering the world by cells of 5 ' of arc angle in size, i.e. approximately $10 \mathrm{~km}$ at mid-latitude. There is one value per month; daily values are obtained by interpolation in time. As these are typical values of $T_{L}$ for a month, there is no change in clear-sky irradiation from one year to another: the hourly values for a given day are the same whatever the year. This is one of the reasons for discrepancies between the actual values of irradiation and those from Heliosat-2.

The application of the method to images of the Meteosat First Generation series of satellites yields the HelioClim-1 database (HC1) covering the period 1985-2005 which proved helpful to assess the long-term variations in the northern Africa desert climate (Abdel Wahab et al. 2010). The HelioClim-3 (HC3) database is constructed from images taken by the Spinning Enhanced Visible and InfraRed Imager (SEVIRI) aboard the Meteosat Second Generation satellites. Each image is processed to yield radiation values at $15 \mathrm{~min}$ intervals, with a spatial resolution at nadir of $3 \mathrm{~km}$, starting 
from 2004. For a given pixel, the daily irradiation is calculated with all images available. Then, a monthly average of the available daily irradiation yields $G$. Besides the differences in images input to the method, the main difference in the implementation of Heliosat-2 between HC1 -detailed in Lefèvre et al. (2007)- and HC3 lies in the exploitation of the method of Cros et al. (2006) that combines the radiances of the two narrow visible bands of SEVIRI to produce broadband radiances that are almost identical to those observed in the broadband channel of the Meteosat First Generation satellites for which Heliosat-2 was developed. The current version of $\mathrm{HC} 3$ is HC3v3 and is used in this study. It covers the period from $1^{\text {st }}$ February 2004 up to now. The SoDa Service (www.soda-is.com) provides easy access to the HelioClim databases (Gschwind et al. 2006).

\subsection{EMs and the YKY model}

The number of EMs to estimate $G$ from available meteorological parameters is considerable in the scientific literature. Ten published methods were selected according to their data requirements and their practical applicability, which was judged mainly by availability of the necessary empirical coefficients (Trnka et al., 2005). These models are based on different meteorological parameters such as $S, T_{a}$, $T_{\max }, T_{\min }, R H, C_{m}$, and $P$ which are available by any synoptic weather station. Table 2 lists the ten selected models. In this Table, $G_{0}$ denotes the monthly mean of daily irradiation on a horizontal surface at the top of the atmosphere. Several models compute $W$ by the formula proposed by Leckner (1978):

$W=0.0049 R H\left[\exp \left(26.23-5416 / T_{a}\right)\right] / T_{a}$

where $W$ is in $\mathrm{cm}, T_{a}$ is in $\mathrm{K}$, and $R H$ in $\%$.

Each EM has adjustable parameters, or variables, which can be adjusted in order to achieve close agreement between estimates and ground measurements of $G$. Each EM was fitted on the set of $G$ measurements available in the ensemble of the stations for the period 1980 to 1990. The coefficients of the ten EMs are shown in Table 2, together with the accuracy of adjustment (standard error of estimate, SEE).

The Yang, Koike, Ye model (YKY) is a hybrid model in the sense that it combines an explicit formulation of the radiative transfer in the cloudless atmosphere and an 
empirical model of the extinction due to the clouds expressed as a sole function of $S$. The model was originally developed by Yang et al. (2001) and Yang and Koike (2002) and then further improved in Yang et al. (2006) by introducing global datasets as input.

The clear-sky model in YKY estimates the monthly mean of daily irradiation under clear sky $(G c)$ by taking into account permanent gases, ozone and water-vapour absorption, molecular and aerosol scattering. Of particular importance under clearskies are the aerosols properties (Kondratyev et al. 2005). YKY makes use of the Global Aerosol Data Set (GADS). As the optical depth of ozone, the authors have developed an empirical formula using zonal means of ozone content computed from the data sets of TOMS (Total Ozone Mapping Spectrometer) aboard Nimbus 7 from 1978 to 1993 and Earth Probe from 1996 to 2003. $W$ is computed from Eq. (3), using inputs from the meteorological sites. YKY computes $G$ from $G c$ and $S$ :

$G=G c\left[0.2777+0.8636 S-0.1413 S^{2}\right]$

\section{Results and discussion}

For each site, and all sites together, $G$ from $\mathrm{HC} 3 \mathrm{v} 3$ and from EMs and YKY model were compared to ground measurements, noted $G_{o b s}$, for the period 2004-2009. Following the ISO standard (1995), deviations were computed by subtracting $G_{o b s}$ for each month and each site from $G$ from HC3v3, EMs and YKY, respectively. The deviations are summarized by the bias -i.e. the mean of the deviation,- the root mean square error (RMSE), and the squared correlation coefficient $\mathrm{R}^{2}$, which accounts for the quantity of information explained by a given method. The relative bias and relative RMSE are the bias, respectively RMSE, divided by the mean value of $G_{o b s}$ for the whole period.

\subsection{Statistical performance for individual sites}

Tables 3 and 4 present the bias and RMSE for each site and each model. At first glance, it appears that the sites Rafah and Nekhel, and to a lesser extent Hurgada, Bathtiem and Malwi, do not produce the same results in the other sites for a given model, for most models. El-Metwally (2004) noted the difficulty to estimate cloudy situations due to the frequent occurrence of fog in the northernmost part of Egypt 
particularly at Rafah. This may explain why Rafah often exhibits bad performance. In addition, the low number of data is another cause for large errors, and this is the case at the three stations: Nekhel, Rafah, and Hurgada, which have less than 14 months, and at Bahtiem (23 months) and Malwi (24 months) (Table 1).

If these sites are set aside, one observes that the bias for $\mathrm{HC} 3 \mathrm{v} 3$ ranges between $0.8 \mathrm{MJ} \mathrm{m}^{-2}$ and $0.9 \mathrm{MJ} \mathrm{m}^{-2}$, and the RMSE is in the range 1.1-2.1 $\mathrm{MJ} \mathrm{m}^{-2}$. YKY has a tendency to underestimate -bias ranges between $-1.3 \mathrm{MJ} \mathrm{m}^{-2}$ and $0.1 \mathrm{MJ} \mathrm{m}^{-2}$-, with a RMSE ranging from 0.8 to $2.0 \mathrm{MJ} \mathrm{m}^{-2}$. The other EMs tend to overestimate $G$ and most often exhibit greater RMSEs than those for HC3v3 or YKY. In addition, it should be noted that the performance of HC3v3 and YKY is fairly independent of the site. Other EMs exhibit small dependency with respect to the site. On the contrary, EM\#6, EM\#7, EM\#8, and EM\#10 have performance that depends strongly on the site. EM\#10 shows the worst performance. These two latter observations are confirmed by the large value of SEE for these models in Table 2.

As a whole, one may conclude that HC3v3, YKY, EM\#2, and EM\#3 are the only models whose results are fairly independent of the site under concern, i.e. they can be used in whole Egypt with the same confidence. Tables 3 and 4 show that the accuracy of the EMs does not increase as the number of inputs to the EM increases. For example, EM\#2 and EM\#3 use only $S$ as input and offer better performance than the other EMs.

Fig. 1 shows the seasonal variation of $G$ observed at Asyut in 2004-2009 as estimated by HC3v3, YKY, EM\#3, EM\#8 and EM\#9. These models have been arbitrarily selected for illustration. The correlation coefficient between $\mathrm{HC} 3 \mathrm{v} 3$ and $G_{o b s}$ is large as for the other models, except for EM\#8. HC3v3 overestimates $G$ for the years 2004 and 2005 and then reproduces $G_{o b s}$ well. The already mentioned underestimation by YKY is illustrated in this Figure. Except for the years 2004 and 2005, HC3v3 reproduces better the change in $G$ than the other models presented.

\subsection{Statistical performance for all data merged}


Table 5 reports on the performance of each model when all data for 2004-2009 and all stations are merged (518 samples). In this Table, HC3v3 exhibits a small overestimation of $0.4 \mathrm{MJ} \mathrm{m}^{-2}$ (2\% of the mean observed value $\left.G_{o b s}\right)$. Most EMs and YKY offer low bias, except EM\#1, EM\#4, EM\#5, EM\#6, EM\#9 and EM\#10. The cause of the low bias is likely due to the fitting of the parameters of model on $G_{o b s}$ though this fitting does not guarantee a low bias. The RMSE for HC3v3 is $1.8 \mathrm{MJ} \mathrm{m}^{-2}$ ( $9 \%$ of the mean observed value $G_{o b s}$ ). This is better or similar to the other models, which is a good result per se.

Figure 2 displays the variation of RMSE as a function of the month for each model. The RMSEs are maxima in April, June-July and October and minima in winter months for most models, except for EM\#8 and EM\#10. The April maximum may be explained by the large fluctuations in aerosols in the form of dust storms -the socalled Khamasin depressions- coming from the Great Sahara which cause deterioration in the vertical atmospheric transmittance (Tadros et al., 2002; El-Wakil et al., 2001; El-Metwally et al. 2008, 2010, 2011; El-Metwally, 2013). These shortterm fluctuations cannot be reproduced by the present models. The October maximum may be due to the northern extension of the Sudan monsoon trough which is occasionally accompanied by dust storms, in addition to a slight increase in precipitable water vapour (El-Wakil et al, 2001). In summer, Egypt experiences high air temperatures, large transparency in the vertical direction with prevailing semitransparent clouds if cloudy (El-Metwally 2004). However, the sky is often turbid due to a deep layer of fine-dust particles associated with continental tropical air. The dust content falls markedly when Mediterranean air arrives, associated with fine weather cumulus. These climatic characteristics together with the fact that $G$ reaches maximum in June and July may explain the summer maximum in RMSE. The RMSE for $\mathrm{HC} 3 \mathrm{v} 3$ is close to $1 \mathrm{MJ} \mathrm{m}^{-2}$ during winter months and October and less than the other models. It is similar to the RMSE of the other EMs for the other months.

$G_{o b s}$ has been divided in three classes: low $\left(G<10 \mathrm{MJ} \mathrm{m}^{-2}\right)$, medium $\left(10 \mathrm{MJ} \mathrm{m}^{-2}<G<20 \mathrm{MJ} \mathrm{m}^{-2}\right)$ and high $\left(G>20 \mathrm{MJ} \mathrm{m}^{-2}\right)$ and the model performances have been assessed for each class (Table 6). HC3V3 exhibits low bias and RMSE in the low class $\left(\sim 0.2 \mathrm{MJ} \mathrm{m}^{-2}\right.$ and $0.9 \mathrm{MJ} \mathrm{m}^{-2}$, respectively) and medium class $\left(\sim 0.0 \mathrm{MJ} \mathrm{m}^{-2}\right.$ 
and $1.5 \mathrm{MJ} \mathrm{m}^{-2}$, respectively). These performances are the best of all models together with YKY included. On the contrary, HC3v3 does not perform well in the high class. The bias amounts to $0.5 \mathrm{MJ} \mathrm{m}^{-2}$ and RMSE to $1.8 \mathrm{MJ} \mathrm{m}^{-2}$. YKY does not perform well at high class for all stations. Many EMs exhibit lower bias and lower RMSE than those of HC3v3 and YKY at the high class.

Performances may be analysed as a function of the cloudiness. Following Barbaro et al. (1981), three classes are defined by $\mathrm{Cm}$ : clear sky (0-2 oktas), partially cloudy sky (3-5 oktas) and overcast sky (6-8 oktas). RMSE, bias and $R^{2}$ are displayed in Figure 3 for each cloudiness class. Fig. 3a shows that the RMSEs for HC3v3 and YKY do not depend on the class. This independence of the performances of $\mathrm{HC} 3 \mathrm{v} 3$ with respect to the cloudiness class holds also for the bias and $R^{2}$ (Fig $3 \mathrm{~b}, \mathrm{c}$ ). This is less true for YKY and all EMs. As a whole, the RMSEs are relatively greater for cloudy conditions than for the clear ones. In Fig. 3b, the bias for HC3v3 is smaller than that of most of models for clear, partially cloudy and overcast conditions. As a whole, EMs show overestimation of $G$ (positive bias). However, YKY underestimates $G$ for all classes as well as EM\#7 for clear conditions and EM\#8 for clear and partially-

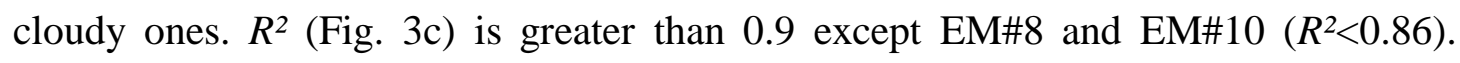
Finally, HC3v3 gives better results than most of models for all classes, particularly for partial and overcast classes. However, most of EMs (1 to 6 and 9) exhibit lower RMSEs for clear sky.

Fig. 4 shows the scatter plots of $G$ estimates versus measurements for all data merged. The estimates show a general agreement with measurements, except for two models (8 and 10) which exhibit very large scatter. The parameters of the least-square regression line between the estimates and the measurements are provided in the graphs. For most models, the slope is not significantly different from 1, except for EM\#7 and EM\#10. $R^{2}$ is greater than 0.89 for all models, except for EM\#8 and EM\#10 (0.67 and 0.60, respectively). The slope (1.01) and intercept (0.09) values for $\mathrm{HC} 3 \mathrm{v} 3$ reflect better performance than the other models; most data points are around the $1: 1$ line. 


\section{Conclusions}

It was found that $\mathrm{HC} 3 \mathrm{v} 3$ can reproduce observed monthly means of daily irradiation at several sites in Egypt. As a whole, a slight overestimation of $0.4 \mathrm{MJ} \mathrm{m}^{-2}$ (2\% of the mean of the observations $G_{o b s}$ ) was found, while the RMSE was $1.8 \mathrm{MJ} \mathrm{m}^{-2}$ ( $9 \%$ of the mean observed value). $R^{2}$ was greater than 0.9 . This performance is better or similar to the other models. The regression line between estimates and observations exhibits a slope of 1.01 and an intercept of $0.09 \mathrm{MJ} \mathrm{m}^{-2}$, reflecting better agreement with the measurements than for the other models. HC3v3 shows remarkable constant performances as a function of the site, the month, the irradiation itself $(G)$ or cloudiness, though its performance should be improved for clear skies.

As devices measuring solar radiation are scarce, many empirical models have been developed to estimate monthly means of daily irradiation using available meteorological parameters as surrogates. These models are often used because of their speed in execution and their simplicity of use. Quite often, coefficients of the EMs are not available for the region of interest and those determined for an adjacent region or another region of similar climate are applied. This increases the error of the EMs. The present study demonstrates that as a whole, $\mathrm{HC} 3 \mathrm{v} 3$ should be preferred to empirical models when estimating monthly means of daily solar irradiation in Egypt. One may wonder why $\mathrm{HC} 1$ or $\mathrm{HC} 3$ or similar data sets from Eumetsat Satellite Application Facilities (Ineichen et al. 2009) are not more often used instead of empirical models since the availability of remote sensing in this domain is known for more than 20 years. We believe that part of the answer lies in the lack of awareness of these data sets and their performances by researchers and other practitioners. Efforts should be pursued in publishing studies similar to the present one. Another concern is also the easy access to these data sets and removal of all barriers felt by practitioners, such as format of the outputs, units, selection of specific sites etc.

The performance for $\mathrm{HC} 3 \mathrm{v} 3$ is in good agreement with that reported by Abdel Wahab et al. (2010) for HC1. In their study, they used 8 sites out of the 14 sites used here in the period 1985-2005 instead of 2004-2009. One may conclude that both data sets are consistent in this region, and that long-term monthly means of daily irradiation starting from 1985 can be created by the concatenation of both data sets. 
The present study adds evidence that solar irradiation can be assessed at the surface of the earth from images acquired by meteorological satellites. The derived performances are currently similar to or better than those obtained by empirical models. By using the most recent results in atmospheric optics, remote sensing will be the most accurate and efficient way to assess solar radiation in the near future. The results clearly show that the $\mathrm{HC} 3 \mathrm{v} 3$ data can be used for mapping global horizontal solar irradiation over Egypt. This accuracy is a great achievement for a country such as Egypt with very sparse radiometric network and frequently unreliable measured irradiation data for the purpose of producing a high quality solar radiation atlas of the country.

\section{Acknowledgements}

The authors are grateful to the Egyptian Meteorological Authority and the World Radiation Data Centre (WRDC) for the provision of ground measurements. The authors thank the company Transvalor which is taking care of the SoDa Service, therefore permitting an efficient access to HelioClim databases. The authors also thank Prof. Kun Yang for providing the source code of the YKY model. The authors acknowledge the help of the anonymous reviewers whose fruitful comments contributed to increase the quality of the article.

\section{References}

ABDALLA, Y.A.G., 1994, New correlation of global solar radiation with meteorological parameters for Bahrain. International Journal of Solar Energy, 16, $111-20$.

ABDEL WAHAB, M., EL-METWALly, M., HASSAN, R., LEFÈVRE, M., OUMBE, A. and WALD, L., 2010, Assessing surface solar irradiance and its longterm variations in the northern Africa desert climate using Meteosat images. International Journal of Remote Sensing, 31, 261-280, doi: $10.1080 / 01431160902882645$.

ACULININ, A., 2008, Latitudinal variability of surface solar radiation in Moldova. Moldavian Journal of the Physical Sciences, 7, 247-253.

AKSOY, B., 2011, Solar radiation over Turkey and its analysis, International Journal of Remote Sensing, 32, 6261-6272, doi:10.1080/01431161.2010.508056. 
AL-JUMAILY, K.J., AL-SALIHI, A.M. and AL-TAI, O.T., 2010, Evaluation of Meteosat- 8 measurements using daily global solar radiation for two stations in Iraq. International Journal of Energy and Environment, 1,635-642.

ÅNGSTRÖM, A., 1924, Solar and terrestrial radiation. Quarterly Journal of the Royal Meteorological Society, 50, 21-125.

BARBARO, S., CANNATA, G., COPPOLINO, S., LEONE, C., and SINGAGRA, E., 1981, Correlation between relative sunshine and state of the sky. Solar Energy 26, 537-550.

BLANC, P., GSCHWIND, B., LEFÈVRE M. and WALD, L., 2011, The HelioClim Project: Surface solar irradiance data for climate applications. Remote Sensing, 3, 343-361, doi:10.3390/rs3020343.

BRISTOW, K.L. and CAMPBELL, G.S., 1984, On the relationship between incoming solar radiation and daily maximum and minimum temperature. Agricultural and Forest Meteorology, 31, 159-166.

CANO, D., MONGET, J.M., AlBUISSON, M., GUILlARD, H., REGAS, N. and WALD, L., 1986, A method for the determination of the global solar radiation from meteorological satellite data. Solar Energy, 37, 31-39.

CROS, S., ALBUISSON, M. and WALD, L., 2006, Simulating Meteosat-7 broadband radiances at high temporal resolution using two visible channels of Meteosat-8. Solar Energy, 80, 361-367.

DIABATÉ, L., BLANC, P. and WALD, L., 2004, Solar radiation climate in Africa. Solar Energy, 76, 733-744.

DIABATÉ, L., DEMARCQ, H., MICHAUD-REGAS, N. and WALD, L., 1988, Estimating incident solar radiation at the surface from images of the Earth transmitted by geostationary satellites: the Heliosat Project. International Journal of Solar Energy, 5, 261-278.

DÜRR, B. and ZELENKA, A., 2009, Deriving surface global irradiance over the Alpine region from Meteosat Second Generation data by supplementing the Heliosat method. International Journal of Remote Sensing, 30, 5821-5841.

EL-METWALLY, M., 2004, Simple new methods to estimate global solar radiation based on meteorological data in Egypt. Atmospheric Research, 69, 217-239. 
EL-METWALLY, M., 2005, Sunshine and global solar radiation estimation at different sites in Egypt. Journal of Atmospheric and Solar-Terrestrial Physics, 67, 1331-1342.

EL-METWALLY, M., 2013, Indirect determination of broadband turbidity coefficients over Egypt. Meteorology and Atmospheric Physics, 119, 71-90, doi:10.1007/s00703-012-0223-7.

EL-METWALLY, M., ALFARO, S.C., ABDEL WAHAB, M. and CHATENET, B., 2008, Aerosol characteristics over urban Cairo: seasonal variations as retrieved from Sun photometer measurements. Journal of Geophysical Research, 113, D14219, doi:10.1029/2008JD009834.

EL-METWALly, M., ALFARO, S.C., ABDEL WAHAB, M.M., FAVEZ, O., MOHAMED, Z. and CHATENET, B., 2011, Aerosol properties and associated radiative effects over Cairo (Egypt). Atmospheric Research, 99, 263-276.

EL-METWALLY, M., ALFARO, S.C., ABDEL WAHAB, M.M., ZAKEY, A.S. and CHATENET, B., 2010, Seasonal and inter-annual variability of the aerosol content in Cairo (Egypt) as deduced from the comparison of MODIS aerosol retrievals with direct AERONET measurements. Atmospheric Research, 97, 14-25.

EL-WAKIL, S.A., EL-METWALLY, M. and GUEYMARD, C., 2001, Atmospheric turbidity of urban and desertic areas of the Nile basin in the aftermath of Mt. Pinatubo's eruption. Theoretical and Applied Climatology, 68, 89-108, doi:10.1007/s007040170056.

GARG, H.P. and GARG, S.T., 1982, Prediction of global solar radiation from bright sunshine hours and other meteorological parameters. In: Solar-India, Proceedings of the National Solar Energy Convention. Allied Publishers, New Delhi, 1.004-1.007.

GEIGER, M., DIABATÉ, L., MÉNARD, L. and WALD, L., 2002, A web service for controlling the quality of measurements of global solar irradiation. Solar Energy, 73, 475-480.

GSCHWIND, B., MÉNARD, L., ALBUISSON, M. and WALD, L., 2006, Converting a successful research project into a sustainable service: The case of the SoDa Web service. Environmental Modelling \& Software, 21, 1555-1561.

GUL M.S, MUNEER T, and KAMBEZIDIS H.D., 1998. Models for obtaining solar radiation data from other meteorological data. Solar Energy, 64, 99-108. 
INEICHEN, P., BARROSO, C. S., GEIGER, B., HOLLMANN, R., MARSOUIN, A. and MUELLER, R., 2009, Satellite Application Facilities irradiance products: hourly time step comparison and validation over Europe. International Journal of Remote Sensing, 30, 5549-5571, doi:10.1080/01431160802680560.

ISO, 1995, Guide to the Expression of Uncertainty in Measurement, 1st ed. International Organization for Standardization: Geneva, Switzerland.

KANDIRMAZ, H. M., YEGINGIL, L., PESTEMALCI, V. and EMRAHOGLU, N., 2004, Daily global solar radiation mapping of Turkey using Meteosat satellite data. International Journal of Remote Sensing, 25, 2159-2168, doi:10.1080/01431160310001618743.

KONDRATYEV, K. Y., IVLEV, L. S., KRAPIVIN, V. F. and VAROTSOS, C. A., 2005, Atmospheric Aerosol Properties: Formation, Processes and Impacts. Springer Praxis, $608 \mathrm{p}$.

LECKNER, B., 1978, The spectral distribution of solar radiation at the earth's surface-elements of a model. Solar Energy, 20, 143-150.

LEFÈVRE, M., DIABATÉ, L. and WALD, L., 2007, Using reduced data sets ISCCPB2 from the Meteosat satellites to assess surface solar irradiance. Solar Energy, 81, 240-253.

LINKE, F., 1922. Transmissions-Koeffizient und Trübungs faktor. Beitraege zur Physik der Atmosphaere, 10, 91-103.

MAGHRABI, A.H., 2009, Parameterization of a simple model to estimate monthly global solar radiation based on meteorological variables, and evaluation of existing solar radiation models for Tabouk, Saudi Arabia. Energy Conversion and Management, 50, 2754-2760.

MARIE-JOSEPH, I., LINGUET, L., GOBINDDASS, M.L. and WALD L., 2013, On the applicability of the Heliosat-2 method to assess surface solar irradiance in the Intertropical Convergence Zone, French Guiana. International Journal of Remote Sensing, 34, 3012-3027, doi:10.1080/01431161.2012.756598.

MARTÍNEZ-LOZANO, J.A., TENA, F., ONRUBIA, J., and DE LA RUBIA, J., 1984, The historical evolution of the Angstrom formula and its modifications: Review and bibliography. Agricultural and Forest Meteorology 33, 109-128.

MÖSER, W. and RASCHKE, E., 1984, Incident solar radiation over Europe estimated from Meteosat data. Journal of Applied Meteorology, 23, 166-170. 
MORADI, I., MUELLER, R., ALIJANI, B. and GHOLAM, A., 2009, Evaluation of the Heliosat-II method using daily irradiation data for four stations in Iran. Solar Energy, 83, 150-156.

MOUSSU, G., DIABATÉ, L., OBRECHT, D. and WALD, L., 1989, A method for the mapping of the apparent ground brightness using visible images from geostationary satellites. International Journal of Remote Sensing, 10, 7, 1207-1225.

OMRAN, M.A., 2000, Analysis of solar radiation over Egypt. Theoretical and Applied Climatology, 67, 225-240.

PINKER, R.T. and LASZLO, I., 1992, Modeling surface solar irradiance for satellite applications on a global scale. Journal of Applied Meteorology, 31, 194-211.

PRESCOTT, J.A., 1940, Evaporation from water surface in relation to solar radiation. Transactions and Proceedings of the Royal Society of South Australia, 46, 114-118.

REHMAN, S. and HALWANI, T. 1997, Global solar radiation estimation. Renewable Energy, 12, 369-85.

REMUND, J., WALD, L., LEFÈVRE, M., RANCHIN, T. and PAGE, J., 2003, Worldwide Linke turbidity information. In Proceedings of ISES Solar World Congress, 16-19 June, Göteborg, Sweden, CD-ROM published by International Solar Energy Society.

RIGOLLIER, C., BAUER, O. and WALD, L., 2000, On the clear sky model of the 4th European Solar Radiation Atlas with respect to the Heliosat method. Solar Energy, 68, 33-48.

RIGOLLIER, C., LEFÈVRE, M. and WALD, L., 2004, The method Heliosat-2 for deriving shortwave solar radiation from satellite images. Solar Energy, 77, 159-169.

SUEHRCKE, H., 2000, On the relationship between duration of sunshine and solar radiation on the earth's surface: Ångström's equation revisited. Solar Energy, 68, 417-425, doi: 10.1016/S0038-092X(00)00004-9.

SUPIT, I. and KAPPEL, R.R.V., 1998, A simple method to estimate global radiation. Solar Energy, 63, 146-150.

TADROS, M.T.Y., EL-METWALLY, M. and HAMED, A.B., 2002, Determination of Ångström coefficients from spectral aerosol optical depth at two sites in Egypt. Renewable Energy, 27, 621-645. 
TRNKA, M., ŽALUD, Z., EITZINGER, J. and DUBROVSKY, M., 2005, Global solar radiation in Central European lowlands estimated by various empirical formulae. Agricultural and Forest Meteorology, 131, 54-76.

VAZQUEZ, M., IZQUIERDO, P., SANTOS, J.M., PRADO, M.T. and MAGRO, C., 2009, Monthly and yearly maps of daily average global solar radiation of the Madeira Archipelago (Portugal), obtained from Meteosat images and six meteorological stations. In Proceedings ISES Solar World Congress 2007, 2641-2645, doi: 10.1007/978-3-540-75997-3_533.

WALD, L., BLANC, P., LEFÈVRE, M. and GSCHWIND, B., 2011, The performances of the HelioClim databases in Mozambique. In Proceedings ISES Solar World Congress 2011, 28 August - 2 September 2011, Kassel, Germany. Vol 'Resource Assessment', 268-275.

WANG, J., WHITE, K. and ROBINSON, G. J., 2000, Estimating surface net solar radiation by use of Landsat-5 TM and digital elevation models. International Journal of Remote Sensing, 21, 31-43, doi:10.1080/014311600210975.

WLOCZYK, C. and RICHTER, R., 2006, Estimation of incident solar radiation on the ground from multispectral satellite sensor imagery. International Journal of Remote Sensing, 27, 1253-1259, doi:10.1080/01431160500185433.

WMO, 1981, Meteorological aspects of the utilization of solar radiation as an energy source. World Meteorological Organization, Geneva, Switzerland. WMO Tech. Note 172, WMO-No. 557, 289 p.

WRC, 1985, Sixth international pyrheliometer comparison (IPC VI). Working Report No. 137. Davos, Switzerland, 1-18 October 1985. Published by World Radiation Center, Davos, Switzerland.

WRC, 1995, International pyrheliometer comparison (IPC VII). Working Report No. 188. Davos: Switzerland, 25 September-13 October 1995. Published by World Radiation Center, Davos, Switzerland.

YANG, K., HUANG, G.W. and TAMAI, N., 2001, A hybrid model for estimating global solar radiation. Solar Energy, 70, pp. 13-22.

YANG, K. and KOIKE, T., 2002, Estimating surface solar radiation from upper-air humidity. Solar Energy, 72, 177-186. 
YANG, K., KOIKE, T. and YE, B., 2006, Improving estimation of hourly, daily, and monthly downward shortwave radiation by importing global data sets. Agricultural and Forest Meteorology, 137, 43-55. 


\section{Table captions:}

Table 1: List of the 14 meteorological stations in Egypt, their geographical coordinates (latitude: $\phi$, longitude: $\psi$, and altitude above mean sea level: $H$ ) and the average of air temperature $\left(T_{a}\right)$, relative humidity $(R H)$, relative sunshine duration $(S)$, clearness index and global horizontal irradiation $(G)$ for the period 2004 to 2009, along with number $N$ of samples in $G$ and years (yr) available.

Table 2: List of ten selected EMs and adjusted parameters with the standard error of estimate (SEE). 714 samples from the period 1980 to 1990 were used, except for ElMetwally (2004) and Supit and Van Kappel (1998) with 680 samples. $G$ and $G_{0}$ in MJ m ${ }^{-2}, W$ in cm, $C_{m}$ in oktas, $H$ in $\mathrm{m}, P$ in hPa, $T_{a}, T_{\max }, T_{\min }$ in ${ }^{\circ} \mathrm{C}$.

Table 3: Bias in $\mathrm{MJ} \mathrm{m}^{-2}$ for each model at each station in the period 2004-2009.

Table 4: RMSE in MJ m${ }^{-2}$ for each model at each station in the period 2004-2009.

Table 5: Bias and RMSE in MJ $\mathrm{m}^{-2}$ for each model, all stations merged in the period 2004-2009. Relative bias and relative RMSE are expressed relative to the mean of $G_{\text {obs. }}$.

Table 6: Statistical performance for each class of $G$ : low $\left(G<10 \mathrm{MJ} \mathrm{m}^{-2}\right)$, medium $\left(10 \mathrm{MJ} \mathrm{m}^{-2}<G<20 \mathrm{MJ} \mathrm{m}^{-2}\right)$ and high $\left(G>20 \mathrm{MJ} \mathrm{m}^{-2}\right)$ for all data (2004-2009). 
Table 1:

\begin{tabular}{|c|c|c|c|c|c|c|c|c|c|c|c|}
\hline Station & WMO\# & $\mathrm{N}$ & $\mathrm{yr}$ & $\phi$ & $\psi$ & $\begin{array}{l}\mathrm{H} \\
(\mathrm{m})\end{array}$ & $\begin{array}{c}\mathrm{T}_{\mathrm{a}} \\
\left({ }^{\circ} \mathrm{C}\right)\end{array}$ & $\begin{array}{l}\mathrm{RH} \\
(\%)\end{array}$ & $S$ & $\begin{array}{c}G \\
\left(\mathrm{MJ} \mathrm{m}^{-2}\right)\end{array}$ & $\begin{array}{c}\text { clearness } \\
\text { index }\end{array}$ \\
\hline Sidi Barrani & 301 & 34 & 2.8 & 31.60 & 26.00 & 26 & 20.1 & 70.5 & 0.76 & 18.4 & Zone\#6 \\
\hline Matruh & 306 & 53 & 4.4 & 31.33 & 27.22 & 38 & 20.0 & 65.0 & 0.77 & 19.1 & $0.5-0.65$ \\
\hline Rafah & 335 & 14 & 1.2 & 31.28 & 34.23 & 56 & 19.2 & 71.5 & 0.80 & 15.9 & Zone \#7 \\
\hline Arish & 336 & 48 & 4.0 & 31.08 & 33.82 & 32 & 19.2 & 70.5 & 0.80 & 18.7 & $0.55-0.65$ \\
\hline Wadi El-Natron & 357 & 36 & 3.0 & 30.4 & 30.37 & 49 & 21.6 & 63.6 & 0.79 & 18.2 & Zone \#5 \\
\hline Bahtiem & 369 & 23 & 1.9 & 30.13 & 31.25 & 17 & 21.3 & 64.0 & 0.74 & 17.9 & $0.52-0.65$ \\
\hline Cairo & 371 & 50 & 4.2 & 30.08 & 31.28 & 26 & 22.8 & 53.3 & 0.78 & 17.9 & \\
\hline Nekhel & 452 & 10 & 0.8 & 29.92 & 33.73 & 403 & 20.5 & 40.8 & 0.82 & 15.3 & Zone \#12 \\
\hline Malwi & 389 & 24 & 2.0 & 27.7 & 30.75 & 52 & 20.0 & 54.4 & 0.81 & 19.5 & $0.58-0.67$ \\
\hline Hurgada & 464 & 14 & 1.2 & 27.28 & 33.73 & 7 & 24.6 & 46.0 & 0.86 & 22.2 & \\
\hline Asyut & 392 & 69 & 5.8 & 27.2 & 31.17 & 52 & 23.0 & 51.0 & 0.84 & 20.9 & Zone \#14 \\
\hline South Valley & 403 & 36 & 3.0 & 26.2 & 32.75 & 96 & 25.6 & 27.8 & 0.88 & 21.5 & $0.65-0.69$ \\
\hline Kharga & 435 & 62 & 5.2 & 25.45 & 30.53 & 70 & 25.4 & 38.8 & 0.87 & 21.0 & \\
\hline Aswan & 414 & 47 & 3.9 & 23.97 & 32.78 & 192 & 26.9 & 25.7 & 0.90 & 22.5 & \\
\hline
\end{tabular}


Table 2:

\begin{tabular}{|c|l|c|l|}
\hline No & Reference & $\begin{array}{c}\text { SEE } \\
\left(\mathrm{MJ} \mathrm{m}^{-2}\right)\end{array}$ & Model \\
\hline 1 & $\begin{array}{l}\text { Angström (1924) } \\
\text { and Prescott (1940) }\end{array}$ & 0.03 & $G=G_{0}(0.228+0.527 S)$ \\
\hline 2 & El-Metwally (2005) & 0.04 & $G=G_{0} 0.7^{(1 / S)}$ \\
\hline 3 & Suehrcke (2000) & 0.03 & $G=G_{0} 0.7 S^{(1 / 2)}$ \\
\hline 4 & $\begin{array}{l}\text { Garg and Garg } \\
(1982)\end{array}$ & 0.03 & $G=G_{0}(0.219+0.526 S+0.004 \mathrm{~W})$ \\
\hline 5 & $\begin{array}{l}\text { Rehman and } \\
\text { Halwani (1997) }\end{array}$ & 0.03 & $\begin{array}{l}G=G_{0}(0.212+0.537 S+0.013 \cos \phi- \\
0.003 \cos \psi+0.00003 H)\end{array}$ \\
\hline 6 & $\begin{array}{l}\text { Bristow and } \\
\text { Campell (1984) }\end{array}$ & 0.05 & $\begin{array}{l}G=1.865 G_{0}\left[1-\exp \left(-0.325\left(T_{\max }-\right.\right.\right. \\
\left.\left.\left.T_{\min }\right)\right)^{0.119}\right]\end{array}$ \\
\hline 7 & El-Metwally (2004) & 1.87 & $\begin{array}{l}G=0.6221 G_{0}+0.3706 T_{\max }-0.1402 T_{\min }+ \\
0.2172 C_{m}-7.9936\end{array}$ \\
\hline 8 & $\begin{array}{l}\text { Supit and Van } \\
\text { Kappel (1998) }\end{array}$ & 2.48 & $\begin{array}{l}G=G_{0}\left[0.069\left(T_{\max }-T_{\min }\right)^{(1 / 2)}+\right. \\
0.439\left(1-C_{m} / 8\right)^{(1 / 2)}+0.905\end{array}$ \\
\hline 9 & Abdalla (1994) & 0.03 & $\begin{array}{l}G=G_{0}\left(0.265+0.429 S+0.002\left(T_{a^{-}} 273.25\right)+\right. \\
0.0001 R H)\end{array}$ \\
\hline 10 & Maghrabi (2009) & 3.36 & $\begin{array}{l}G=12.879+5.021 S+0.25\left(T_{a^{-}}-273.25\right)- \\
0.001 P+4.089 \mathrm{~W}-0.172 R H\end{array}$ \\
\hline
\end{tabular}

Table 3:

\begin{tabular}{|c|c|c|c|c|c|c|c|c|c|c|c|c|}
\hline \multirow[t]{2}{*}{ Station } & \multirow[t]{2}{*}{$\mathrm{HC} 3 \mathrm{v} 3$} & \multirow[t]{2}{*}{ YKY } & \multicolumn{9}{|c|}{ EMs } & \multirow[b]{2}{*}{10} \\
\hline & & & 1 & 2 & 3 & 4 & 5 & 6 & 7 & 8 & 9 & \\
\hline $\begin{array}{l}\text { Sidi } \\
\text { Barrani }\end{array}$ & 0.5 & 0.1 & 1.6 & 1.3 & 0.9 & 1.7 & 1.8 & 1.3 & 1.0 & -1.9 & 1.5 & 2.0 \\
\hline Matruh & -0.8 & -1.2 & 0.5 & 0.1 & -0.2 & 0.5 & 0.7 & 0.4 & -0.1 & -2.3 & 0.3 & 1.1 \\
\hline Rafah & 3.3 & 1.5 & 3.1 & 2.8 & 2.4 & 3.2 & 3.4 & 3.6 & 2.2 & 0.0 & 2.9 & 3.6 \\
\hline Arish & -0.6 & -0.8 & 0.9 & 0.5 & 0.2 & 1.0 & 1.2 & 1.2 & 0.0 & -0.7 & 0.6 & 0.9 \\
\hline $\begin{array}{l}\text { Wadi El- } \\
\text { Natron }\end{array}$ & 0.8 & -0.3 & 1.9 & 1.5 & 1.1 & 1.9 & 1.8 & 2.5 & 1.0 & -1.6 & 1.8 & 3.6 \\
\hline Bahtiem & 1.5 & -0.3 & 1.6 & 1.4 & 1.0 & 1.7 & 1.4 & 3.0 & 1.6 & 3.8 & 1.7 & 3.3 \\
\hline Cairo & 0.4 & -0.6 & 1.3 & 1.1 & 0.7 & 1.3 & 1.1 & 1.5 & 0.7 & 0.0 & 1.4 & 4.7 \\
\hline Nekhel & 5.0 & 5.3 & 6.7 & 6.2 & 5.8 & 6.6 & 6.9 & 7.4 & 5.3 & 3.6 & 6.5 & 5.7 \\
\hline Malwi & 1.8 & -1.2 & 0.6 & 0.2 & -0.2 & 0.6 & 0.0 & 1.0 & -0.5 & -1.2 & 0.4 & 1.1 \\
\hline Hurgada & -1.9 & -2.4 & -0.6 & -1.3 & -1.6 & -0.6 & -1.0 & -2.0 & -2.5 & -4.6 & -0.6 & 2.1 \\
\hline Asyut & 0.9 & -1.3 & 0.7 & 0.1 & -0.3 & 0.7 & 0.2 & 0.8 & -1.0 & 0.8 & 0.6 & 1.8 \\
\hline $\begin{array}{l}\text { South } \\
\text { Valley }\end{array}$ & -0.5 & -0.8 & 0.6 & -0.2 & -0.5 & 0.4 & 0.6 & 0.0 & -1.6 & -2.0 & 0.5 & 1.7 \\
\hline Kharga & 0.8 & -0.6 & 1.2 & 0.4 & 0.1 & 1.1 & 1.3 & 1.0 & -0.8 & 0.0 & 1.2 & 3.3 \\
\hline Aswan & -0.6 & -1.0 & 0.4 & -0.5 & -0.8 & 0.3 & 0.5 & -0.5 & -2.2 & -0.9 & 0.5 & 2.1 \\
\hline
\end{tabular}


Table 4:

\begin{tabular}{|c|c|c|c|c|c|c|c|c|c|c|c|c|}
\hline \multirow[t]{2}{*}{ Station } & \multirow[t]{2}{*}{$\mathrm{HC} 3 \mathrm{v} 3$} & \multirow[t]{2}{*}{ YKY } & \multicolumn{9}{|c|}{ EMs } & \multirow[b]{2}{*}{10} \\
\hline & & & 1 & 2 & 3 & 4 & 5 & 6 & 7 & 8 & 9 & \\
\hline $\begin{array}{l}\text { Sidi } \\
\text { Barrani }\end{array}$ & 1.5 & 1.6 & 2.4 & 2.0 & 1.8 & 2.5 & 2.5 & 2.3 & 2.1 & 5.5 & 2.2 & 4.7 \\
\hline Matruh & 1.7 & 1.8 & 1.5 & 1.4 & 1.5 & 1.5 & 1.6 & 2.0 & 2.1 & 4.6 & 1.4 & 4.4 \\
\hline Rafah & 4.0 & 1.9 & 3.4 & 3.0 & 2.6 & 3.5 & 3.7 & 3.7 & 2.5 & 4.5 & 3.2 & 5.3 \\
\hline Arish & 2.1 & 1.7 & 1.7 & 1.5 & 1.4 & 1.7 & 1.8 & 2.1 & 1.8 & 4.2 & 1.5 & 3.8 \\
\hline $\begin{array}{l}\text { Wadi El- } \\
\text { Natron }\end{array}$ & 1.2 & 0.8 & 2.0 & 1.7 & 1.3 & 2.1 & 2.0 & 2.6 & 1.6 & 5.7 & 1.9 & 4.8 \\
\hline Bahtiem & 1.6 & 1.7 & 2.3 & 2.4 & 2.0 & 2.4 & 2.2 & 3.4 & 2.3 & 3.9 & 2.2 & 4.6 \\
\hline Cairo & 1.2 & 1.3 & 1.7 & 1.6 & 1.3 & 1.7 & 1.5 & 2.1 & 1.7 & 3.7 & 1.7 & 5.7 \\
\hline Nekhel & 5.5 & 5.4 & 6.8 & 6.3 & 5.9 & 6.7 & 7.0 & 7.5 & 5.4 & 5.5 & 6.6 & 6.3 \\
\hline Malwi & 2.4 & 2.2 & 2.1 & 1.9 & 1.9 & 2.1 & 2.0 & 2.1 & 2.0 & 4.9 & 2.0 & 3.6 \\
\hline Hurgada & 2.0 & 2.6 & 1.1 & 1.6 & 1.9 & 1.1 & 1.4 & 2.3 & 2.8 & 5.6 & 1.0 & 3.7 \\
\hline Asyut & 1.7 & 2.0 & 1.7 & 1.6 & 1.7 & 1.8 & 1.7 & 1.7 & 2.1 & 3.8 & 1.6 & 3.6 \\
\hline $\begin{array}{l}\text { South } \\
\text { Valley }\end{array}$ & 1.5 & 1.1 & 1.1 & 0.8 & 1.0 & 1.1 & 1.1 & 0.7 & 1.8 & 4.6 & 1.1 & 3.5 \\
\hline Kharga & 1.5 & 0.9 & 1.5 & 0.9 & 0.9 & 1.5 & 1.6 & 1.2 & 1.3 & 4.5 & 1.5 & 4.4 \\
\hline Aswan & 1.1 & 1.3 & 1.2 & 1.2 & 1.4 & 1.2 & 1.2 & 1.1 & 2.5 & 3.5 & 1.0 & 3.3 \\
\hline
\end{tabular}

Table 5

\begin{tabular}{|c|c|c|c|c|c|c|c|c|c|c|c|c|}
\hline \multirow[t]{2}{*}{ Station } & \multirow[t]{2}{*}{$\mathrm{HC} 3 \mathrm{v} 3$} & \multirow[t]{2}{*}{ YKY } & \multicolumn{9}{|c|}{ EMs } & \multirow[b]{2}{*}{10} \\
\hline & & & 1 & 2 & 3 & 4 & 5 & 6 & 7 & 8 & 9 & \\
\hline Bias & 0.4 & -0.6 & 1.2 & 0.6 & 0.3 & 1.2 & 1.1 & 1.2 & -0.2 & -0.5 & 1.1 & 2.5 \\
\hline $\begin{array}{l}\text { Relative } \\
\text { bias }\end{array}$ & $2 \%$ & $-3 \%$ & $6 \%$ & $3 \%$ & $1 \%$ & $6 \%$ & $6 \%$ & $6 \%$ & $-1 \%$ & $-3 \%$ & $6 \%$ & $13 \%$ \\
\hline RMSE & 1.8 & 1.7 & 2.0 & 1.8 & 1.7 & 2.0 & 2.1 & 2.3 & 2.1 & 4.5 & 1.9 & 4.4 \\
\hline $\begin{array}{l}\text { Relative } \\
\text { RMSE }\end{array}$ & $9 \%$ & $9 \%$ & $10 \%$ & $9 \%$ & $9 \%$ & $10 \%$ & $11 \%$ & $12 \%$ & $11 \%$ & $23 \%$ & $10 \%$ & $22 \%$ \\
\hline
\end{tabular}


Table 6

\begin{tabular}{lccc|ccc}
\hline & \multicolumn{3}{c|}{ Bias } & \multicolumn{3}{c}{ RMSE } \\
Models & \multicolumn{3}{c}{$\left(\mathrm{MJ} \mathrm{m}^{-2}\right)$} & & \multicolumn{3}{c}{$\left(\mathrm{MJ} \mathrm{m}^{-2}\right)$} \\
\cline { 2 - 7 } & Low & Medium & High & Low & Medium & High \\
& $G_{\text {obs }}$ & $G_{\text {obs }}$ & $G_{\text {obs }}$ & $G_{\text {obs }}$ & $G_{\text {obs }}$ & $G_{\text {obs }}$ \\
\cline { 2 - 7 } HC3v3 & 0.2 & 0.3 & 0.5 & 0.9 & 1.9 & 1.8 \\
YKY & 0.5 & 0.1 & -1.3 & 0.7 & 1.6 & 1.9 \\
EM\#1 & 1.8 & 1.7 & 0.6 & 1.9 & 2.4 & 1.7 \\
EM\#2 & 1.9 & 1.4 & -0.2 & 2.0 & 2.1 & 1.5 \\
EM\#3 & 1.6 & 1.1 & -0.6 & 1.7 & 1.9 & 1.6 \\
EM\#4 & 1.7 & 1.7 & 0.6 & 1.8 & 2.4 & 1.7 \\
EM\#5 & 1.8 & 1.7 & 0.5 & 1.9 & 2.4 & 1.7 \\
EM\#6 & 3.3 & 2.1 & 0.1 & 3.4 & 2.8 & 1.6 \\
EM\#7 & 2.9 & 1.0 & -1.5 & 2.9 & 1.9 & 2.2 \\
EM\#8 & 1.7 & -0.3 & -0.9 & 2.5 & 3.9 & 5.0 \\
EM\#9 & 1.7 & 1.5 & 0.7 & 1.8 & 2.2 & 1.7 \\
EM\#10 & 5.9 & 3.9 & 1.0 & 6.1 & 5.1 & 3.4 \\
\hline
\end{tabular}




\section{Figure captions:}

Fig. 1: Seasonal variation of $G$ observed at Asyut in 2004-2009 as estimated by HC3v3, YKY, EM\#3, EM\#8 and EM\#9.

Fig. 2: Monthly mean variation of RMSE (MJ m ${ }^{-2}$ ) for all data (2004-2009).

Fig. 3: Statistical performance as function of cloudiness. a) RMSE, b) bias and c) $R^{2}$. Values at overcast sky are located outside the limits of the graph for EM\#8"

Fig. 4: Scatter plots of measured vs. estimated $G$ values for each selected model. The horizontal axis represents measurements and the vertical axis the estimated values. The dashed line represents the 1:1 line 

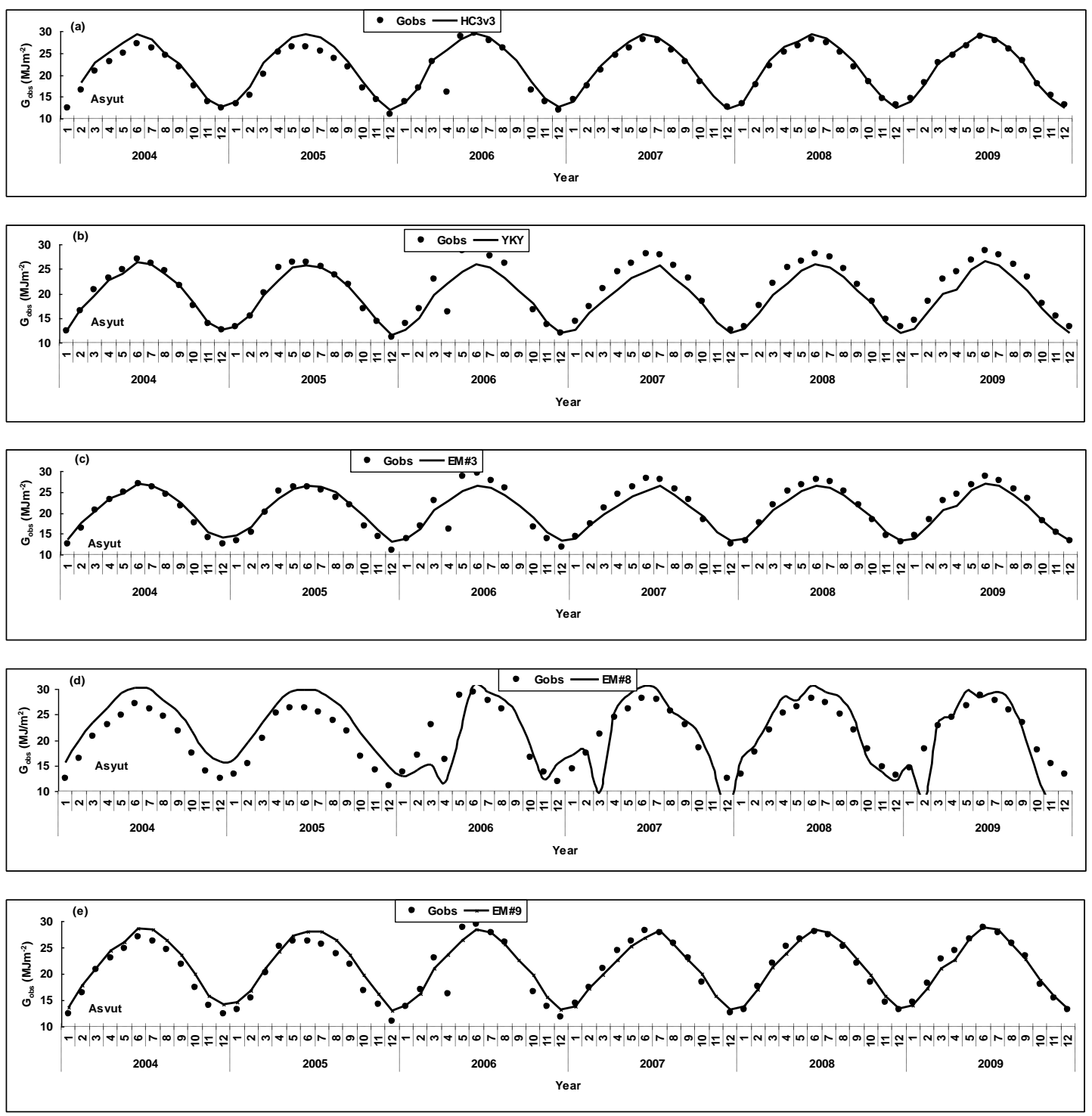

Fig. 1 


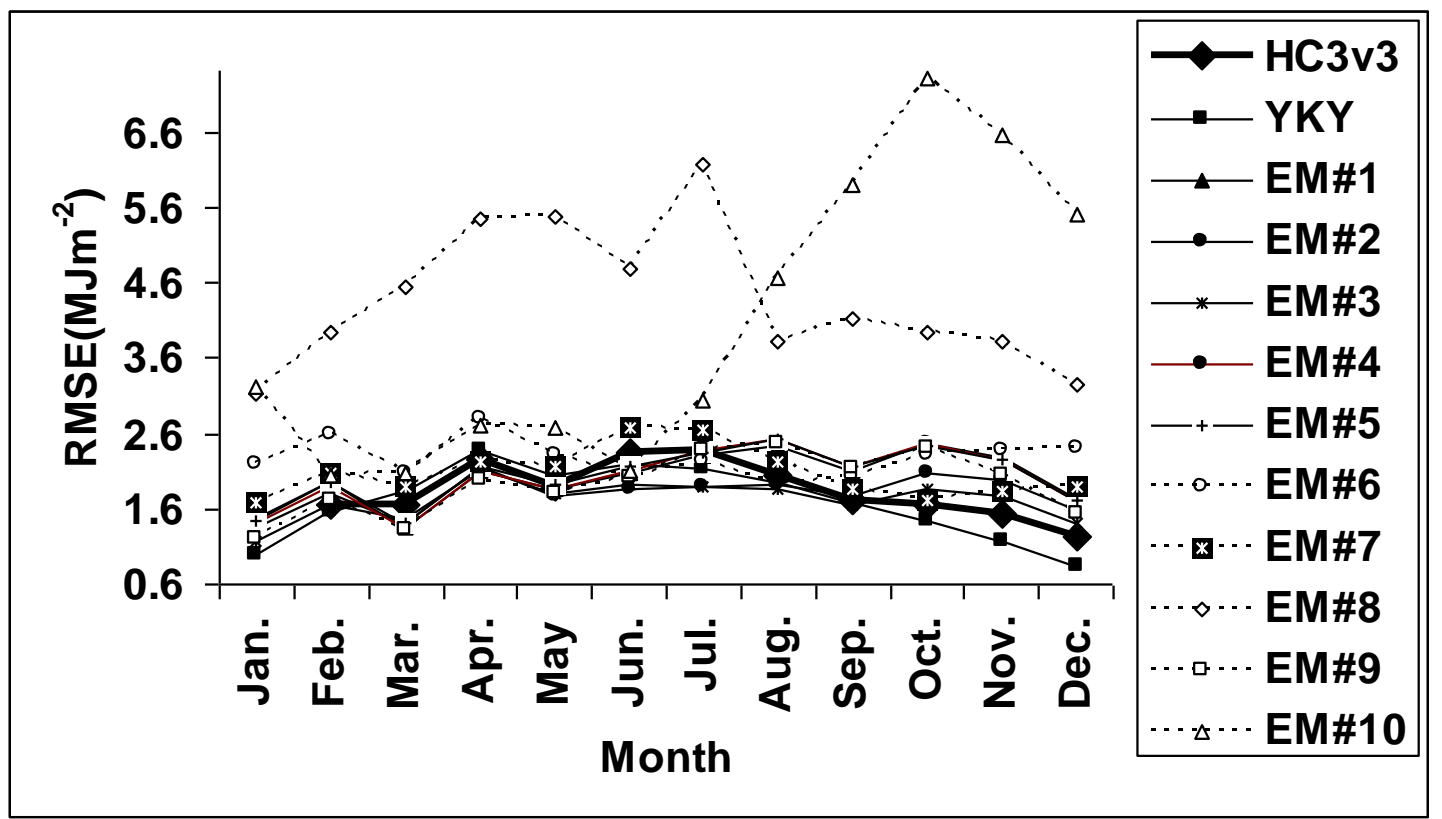

Fig. 2 

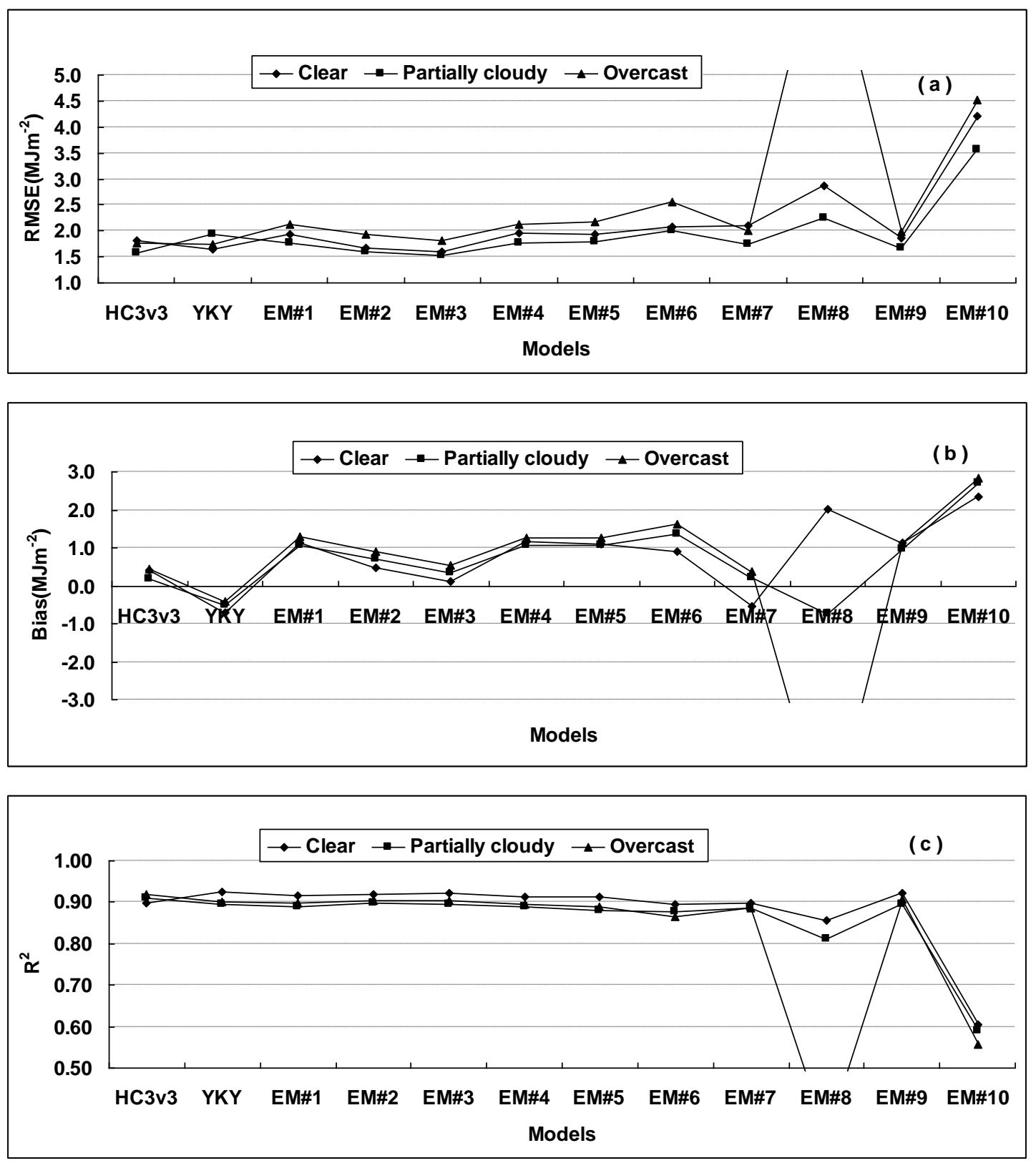

Fig. 3: 


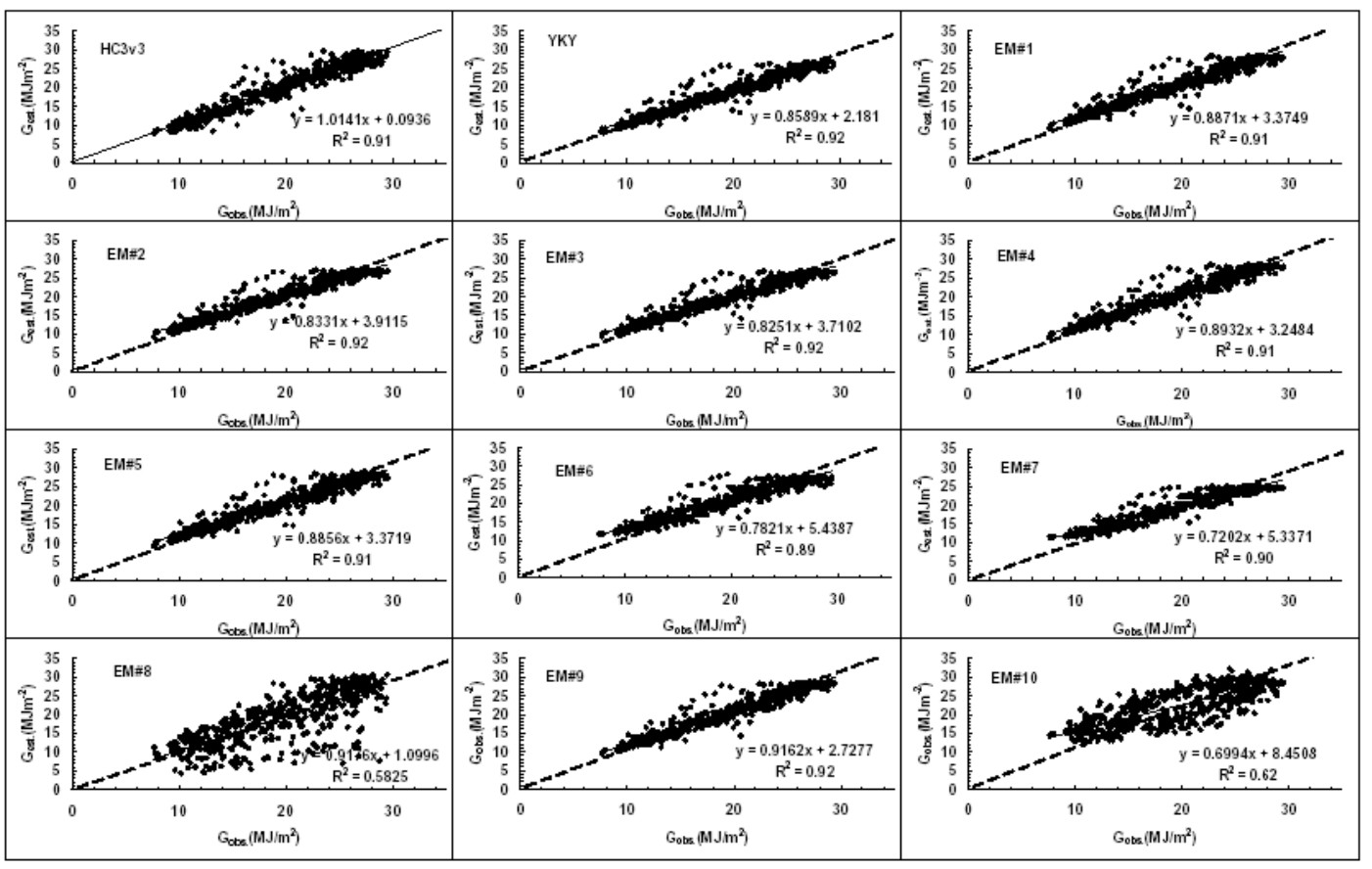

Fig. 4 